\title{
Egy lépést hátra - A magyar Alkotmánybíróság döntése az internetes hozzászólásokért való felelősségről
}

\author{
szólásszabadság az interneten - felelősség az internetes hozzászólásokért - \\ demokratikus vita - személyiségi jogok védelme - szükségességi- \\ arányossági teszt
}

A szólásszabadság korlátozása változatos, soha véget nem érő viták tárgya. Különösen igaz ez a véleményszabadság interneten történő megvalósulása tekintetében. Az internet ugyanis olyan sajátosságokkal rendelkezik - mint például a névtelenség, a technikai nehézségekbe ütköző tartalom-ellenörzés, a kommunikáció határokon átnyúló volta, ${ }^{1}$ az információáramlás rendkívüli gyorsasága és tömegekhez való eljutása -, amelyek a korábban ismert és használt médiumokkal szemben újdonságot jelentenek. Ráadásul az internet folyamatosan fejlődik. Ezek a tulajdonságok több jogterületre kiterjedő szabályozási problémákat okoznak. Arról sem egyeznek a vélemények, hogy egyáltalán szükséges-e részletes állami szabályozás, vagy elegendő lehet a szolgáltatók önszabályozása, illetve az alapelvi szintủ nemzetközi szabályozás. ${ }^{2}$ Vita van arról is, hogy párhuzamot lehet-e vonni az internet és más médiumok között, s lehet-e ez alapján analógiákat alkalmazni. ${ }^{3}$ Nem tisztázott az sem, hogy lehet-e a tartalmakat korlátozni, és ha igen, akkor hogyan és milyen mértékben.

Magyarországon az internettel kapcsolatban sokáig a szabályozás töredezettsége volt a jellemző, így az Alkotmánybíróság sem tudott kimunkálni alapvető alkotmányos elveket az internetes szólásszabadságra vonatkozóan. 2010-ben azonban új médiaszabályozást fogadott el a jogalkotó, amellyel kapcsolatban a nemzetközi környezetben számos bíráló észrevétel fogalmazódott meg. ${ }^{4} \mathrm{~A}$ média teljes lefedé-

* Dr. Balogh Éva PhD-hallgató, Debreceni Egyetem Állam- és Jogtudományi Kar, Alkotmányjogi Tanszék, balogheva27@gmail.com.

1 HaLmAI Gábor: Kommunikációs jogok, Új Mandátum, Budapest, 2002, 91-92.

2 KoltaY András: A szólásszabadság alapvonalai - magyar, angol, amerikai és európai összehasonlitásban, Budapest, Századvég, 2009, 359.

3 E dilemmákról lásd részletesebben Rошвоттом, Jacob: Sajtószabadság és politikai vita a digitális korban, Fundamentum, 2007/2., 5-12.

4 Az Európai Bizottság és az EBESZ médiaszabadsággal foglalkozó képviselöi egyaránt aggályaikat fejezték ki a magyar szabályozással kapcsolatosan (http://hvg.hu/itthon/20110117_mediatv_eubiztos; OSCE: Analysis and Assessment of a Package of Hungarian Legislation and Draft Legislation on Media and Telecommunications, Warsaw, 2010, http://www.osce.org/fom/71218?download=true). Ezt követően az Európai Parlament állásfoglalásában mutatott rá arra, hogy a médiatörvények nem felelnek meg az uniós ér- 
sét célzó új médiatörvények, a sajtószabadságról és a médiatartalmak alapvető szabályairól szóló 2010. évi CIV. törvény (Smtv.) és a médiaszolgáltatásokról és a tömegkommunikációról szóló 2010. évi CLXXXV. törvény (Mttv.) az internetes tartalmakat a tömegkommunikációban betöltött sajátosságaikra tekintettel ugyan, de más médiatartalmakkal egységesen kezelik. Az Alkotmánybíróság a médiatörvények alkotmányosságának vizsgálata során lehetőséget kapott az internetes közlések vizsgálatára. Határozatában az interneten megvalósuló sajtótevékenység korlátozásának határait járta körül, az internetet médiumként vizsgálva. E megállapítások tehát a szerkesztett tartalmakra vonatkoztak. ${ }^{5}$

A közelmúltban a magyar Alkotmánybíróság újabb határozatot hozott az internetes szólásszabadságról. ${ }^{6} A$ döntés több okból jelentős. Egyrészt azért, mert az $A B$ első alkalommal foglalt állást az interneten közzétett tartalmakhoz az olvasók által füzött hozzászólásokról. Másrészt azért, mert ez alapján úgy tủnik, a testület - a korábbi, szólásszabadságot széles körben védő gyakorlatától eltérve - a szólást inkább korlátozó, mintsem megengedő attitűdöt tett magáévá. Jelen tanulmány ennek a döntésnek a bemutatására vállalkozik. Az ismertetés mellett célja a határozat értékelése is, ezért igyekszik az érvelés gyenge pontjaira is rámutatni.

\section{Az ügy körülményei és a panasz}

Az internetes tartalomszolgáltatók önszabályozó társadalmi szervezete (Magyar Tartalomszolgáltatók Egyesülete) egy ingatlanforgalmazással foglalkozó gazdasági társaság hirdetési tevékenységéről készített állásfoglalást, melyet az általa üzemeltetett honlapon közzétett. Az állásfoglaláshoz az internetes oldal olvasói is hozzászóltak. A kommentek közül kettő jogsértő mivolta merült fel. Az üzemeltető a jogsértőnek tekintett tartalomról való tudomásszerzésekor a kommenteket haladéktalanul eltávolította a tárhelyröl. Az érintett gazdasági társaság keresetet nyújtott be többek között az internetes tartalomszolgáltatók önszabályozó társadalmi szervezete ellen, mivel úgy vélte, hogy az állásfoglalás és a hozzá füzött kommentek a jó hírnév védelméhez való jogát sértik.

Az internetes oldalt üzemeltető egyesületet mindhárom fokon ${ }^{7}$ elmarasztalta a bíróság a jó hírnévhez füződő jogok megsértése miatt. A bíróságok szerint az egyesület által üzemeltetett honlapon megjelent cikkhez beküldött két hozzászólás túllépte a véleménynyilvánítás szabadságának megengedett határait. ${ }^{8}$ A marasztaló ítéletek indoka az volt, hogy az oldal üzemeltetője lehetőséget biztosított ezen kommen-

tékeknek és más nemzetközi normáknak [Az Európai Parlament 2011. március 10-i állásfoglalása a magyar médiatörvényröl, P7_TA(2011)0094].

5 165/2011. (XII. 20.) AB határozat, ABK 2011/12., 1292-1302.

6 19/2014. (V. 30.) AB határozat, ABK 2014/17., 812-827.

7 Fővárosi Bíróság 19.P.21.022/2010/7. számú ítélete; Fővárosi Ítélőtábla 8.Pf.21.129/2011/4. számú ítélete; Kúria Pfv.IV.20.217/2012/5. számú ítélete.

8 A bíróság az állásfoglalást nem találta jogsértőnek, csak a hozzá füzött kommenteket. 
tek megjelenítésére, tehát híreszteléssel valósította meg a jó hírnév megsértését. ${ }^{9}$ Ezen nem változtatott, hogy az oldal előzetes moderálás nélkül müködött - azaz az üzemeltető az oldalon való megjelenés előtt nem ismerte a hozzászólások tartalmát -, és az sem, hogy a jogsértő tartalomról való értesülésekor azt haladéktalanul eltávolította a tárhelyröl. Utóbbinak a bíróságok szerint csupán a kártérítési igény és a felróhatóság alóli kimentés kapcsán volt jelentősége. Így a jogsértő tartalom haladéktalan eltávolítása a kártérítés mértékét befolyásolta, de a felelősség alóli mentesülést nem alapozta meg. A döntések értelmében a tárhelyszolgáltatónak számolnia kell azzal, hogy ha különböző hozzászólások elhelyezésére ellenőrzés nélkül biztosít lehetőséget, azok jogsértő volta miatt ő sem mentesülhet a felelősség, illetve a jogsértés megállapítása alól.

A Magyarországi Tartalomszolgáltatók Egyesülete a Kúria ítéletével, illetve az azt megelőző első- és másodfokú bírósági döntésekkel szemben fordult alkotmányjogi panasszal az Alkotmánybírósághoz, kérve azok megsemmisítését.

Az indítványozó szerint a bírósági ítéletek sértik a véleménynyilvánításhoz való jogát, ezért alaptörvény-ellenesek. Véleménye szerint a moderálás nélküli hozzászólást biztosító oldalakat müködtető személyeket és szerveket - az ő értelmezésében az elektronikus kereskedelmi szolgáltatások, valamint az információs társadalmi szolgáltatások egyes kérdéseiröl szóló 2001. évi CVIII. törvény (Ektv.) szerinti közvetítő szolgáltatókat ${ }^{10}$ - a véleménynyilvánítás szabadsága ugyanolyan védelemben részesíti, mint a sajtótermékek kiadását. A szólásszabadságnak ugyanis fontos eleme az interneten való moderálás nélküli közlések közzététele, melyhez az ilyen típusú kommunikációt biztosító tárhelyek szükségesek. Így valósulhat meg az, hogy a vélemények találkozhassanak, és valódi vita jöhessen létre az interneten. Az elözetes moderáció nem tenné lehetővé a gyors reagálást igénylő véleménycserét. A panaszos érvei között szerepelt az is, hogy a véleményszabadság kettős rendeltetésének - azaz a közügyek megvitatásának és az egyéni önkifejezésnek - az internetes kommunikációban is érvényesülnie kell, amelyre alkalmasak az internetes fórumok és hozzászólások.

Az indítványozó szerint a bírói döntések az akkor hatályban lévő Ptk.-t nem az Alaptörvénnyel összhangban értelmezték, mivel a véleménynyilvánítás és a sajtó szabadságát a szükséges és arányos mértéken túl korlátozták. A jó hírnév megsértését ugyanis a hozzászóló követte el, így a véleménynyilvánítás szabadságának aránytalan korlátozását jelenti az olyan értelmezés, mely szerint az is elköveti a jog-

9 Az akkor hatályban lévő 1959. évi IV. törvény a Polgári Törvénykönyvröl vonatkozó rendelkezései:

75. § (1) A személyhez füződő jogokat mindenki köteles tiszteletben tartani. E jogok a törvény védelme alatt állnak. 78. § (1) A személyhez füződő jogok védelme kiterjed a jó hírnév védelmére is.

(2) A jó hírnév sérelmét jelenti különösen, ha valaki más személyre vonatkozó, azt sértő, valótlan tényt állít, híresztel, vagy való tényt hamis színben tüntet fel.

10 2. § (1) I) Közvetítő szolgáltató: az információs társadalommal összefüggő szolgáltatást nyújtó szolgáltató, amely la) az igénybe vevő által biztosított információt távközlö hálózaton továbbítja, vagy a távközlö hálózathoz hozzáférést biztosit (egyszerủ adatátvitel és hozzáférés-biztositás);

lb) az igénybe vevő által biztosított információt távközlő hálózaton továbbítja, és az alapvetően a más igénybe vevők kezdeményezésére történő információtovábbítás hatékonyabbá tételét szolgálja (gyorsítótárolás);

Ic) az igénybe vevő által biztosított információt tárolja (tárhelyszolgáltatás);

Id) információk megtalálását elősegítő segédeszközöket biztosít az igénybe vevő számára (keresőszolgáltatás). 
sértést, aki a közlés tartalmára nincs befolyással, csupán a közlés megjelenítéséhez biztosít eszközt. Emiatt az indítványozó úgy látta, hogy a jogerős bírói döntés következménye a szabad internetes kommunikáció ellehetetlenülése. A fórumrendszert üzemeltetőknek ugyanis túlságosan nagy kockázatot kellene vállalniuk a moderáció nélküli oldalak müködtetésével, hiszen a jogsértő közlésekért annak ellenére, hogy azok tartalmára nincsenek hatással, felelősségük tulajdonképpen objektív.

\section{Az Alkotmánybíróság érvelése}

Az Alkotmánybíróság a panaszt nem találta megalapozottnak, így elutasította. A következőkben a testület érvelésének rekonstruálására törekszem, rávilágítva annak vitatható elemeire.

$A z A B$ az interneten történő véleménynyilvánítás előkérdéseként az információs társadalom és az internetes kommunikáció szabályozását - így az Ektv. szolgáltatóra és közvetítő szolgáltatóra vonatkozó szabályait - tekintette át és értelmezte. Ennek során megállapította, hogy a szolgáltató és a közvetítő szolgáltató felelőssége eltérő. A szolgáltató ugyanis felel az általa közzétett, jogszabályba ütköző tartalomért és az ezzel okozott kárért, a közvetítő szolgáltató viszont bizonyos feltételek fennállása esetén mentesülhet a felelősség alól. ${ }^{11}$ Ennek oka, hogy míg a szolgáltató az információkat maga hozza létre és teszi közzé, a közvetítő szolgáltató nem köteles ellenőrizni az általa csak közvetített információkat, és nem köteles jogellenes tevékenységre utaló tények vagy körülmények felkutatására sem. A testület megvizsgálta az Ektv. vonatkozó szabályainak alapjául szolgáló európai uniós irányelv ${ }^{12}$ által támasztott, az információs társadalommal kapcsolatos szolgáltatásokra vonatkozó követelményeket is.

A testület arra a következtetésre jutott, hogy annak ellenére, hogy a törvény határozottan elkülöníti a két típusú szolgáltatót, azok nem feltétlenül válnak el ilyen élesen. Előfordulhat tehát az, hogy a tartalomszolgáltató, aki lehetővé teszi az általa közzétett közlésekhez kommentek hozzáfüzését, közvetítő szolgáltatóvá is válik. Az így tárolt tartalmakért tehát közvetítő szolgáltatóként, az általa előállítottakért pedig szolgáltatóként felel. Az indítványozó a bíróságok előtt közvetítő szolgáltatói minőségére tekintettel kérte a felelősség alóli mentesülést.

Az alkotmányjogi panasz tárgyát képező rendes bírósági eljárás folyamán az egyes bírói fórumoknak eltérő véleményük volt arról, hogy a kommentek a közlések milyen kategóriájába tartoznak. Az elsőfokú bíróság az olvasói levelekkel egy te-

11 Ektv. 10. § A 2. § Ic) pontjában meghatározott közvetítő szolgáltató akkor nem felel az igénybe vevő által biztosított információért, ha

a) nincs tudomása az információval kapcsolatos jogellenes magatartásról, vagy arról, hogy az információ bárkinek a jogát vagy jogos érdekét sérti;

b) amint az a) pontban foglaltakról tudomást szerzett, haladéktalanul intézkedik az információ eltávolításáról, vagy a hozzáférést nem biztosítja.

12 Az Európai Parlament és a Tanács 2000/31/EK-irányelve (2000. június 8.) a belső piacon az információs társadalommal összefüggő szolgáltatások, különösen az elektronikus kereskedelem, egyes jogi vonatkozásairól (Elektronikus kereskedelemről szóló irányelv). HL L 178, 2000.7.17., 399-414. 
kintet alá tartozónak vélte őket, tehát szerkesztett tartalomnak. Az ítélőtábla szerint nem lehet egyenlöségjelet tenni az internetes hozzászólások és az olvasói levelek közé, pontosan az előzetes szerkesztés a különbség közöttük. A másodfokú bíróság szerint a hozzászólások magánjellegű megnyilvánulások, így nem tartoznak az Ektv. tárgyi hatálya alá, így az indítványozó nem mentesülhetett a közvetítő szolgáltatókra vonatkozó felelösség alapján. Éppen ezért az ügyet a régi Ptk. szerint bírálta el, és megállapította, hogy mivel a jogsértő véleményt tartalmazó hozzászólás az indítványozó honlapján jelent meg, híreszteléssel valósult meg a jó hírnév megsértése. A bíróság szerint az indítványozó maga is jogsértést követett el annak ellenére, hogy a hozzászólások tartalmát előzetesen nem ismerte, és azokat a sértett kívánságára eltávolította. Ezt az indokolást a Kúria is elfogadta. Az Alkotmánybíróságnak tehát azt kellett eldöntenie, hogy ez az értelmezés sérti-e az indítványozó Alaptörvényben biztosított jogát.

A testület ebben a kérdésben arra a megállapításra jutott, hogy a kommentek semmiképp sem minösülhetnek magánjellegü megnyilvánulásnak. A magánközléseket, amelyek csak meghatározott személyeknek szólnak, az Alaptörvény VI. cikke védi, amely a magánélet védelmét biztosítja. A testület szerint a komment nem tekinthető magánközlésnek, hanem a nyilvánosságnak szánt véleménynek, így a IX. cikk, a véleménynyilvánítási szabadság védelmi körébe tartozik. $A z A B$ rámutatott, hogy annak következtében, hogy a hozzászóló személye nem azonosítható be, az oldal müködtetőjét terheli a felelősség. Ezt találja az indítványozó a véleménynyilvánítás és a sajtó szabadságába ütközőnek. Az Alkotmánybíróság szerint elsősorban a sajtószabadság sérül ebben az esetben, tehát a vélemények nyilvánossághoz eljuttatásának szabadsága.

Ez az érvelés azonban vitatható, kérdéses ugyanis, hogy a szóban forgó internetes oldal valóban hasonlítható-e a sajtóhoz. Az Alkotmánybíróság leegyszerüsítette a problémát azzal, hogy azonosította a sajtóval a szóban forgó internetes oldalt, tekintet nélkül annak számos eltérö jellemzőjére. A legfontosabb különbség a következőkben ragadható meg. A sajtó a tömegtájékoztatás eszköze, fö jellemzője a szerkesztett tartalmak közlése, az információk lehető legszélesebb körben való eljuttatása a társadalom tagjai felé, és ezzel a közvélemény formálódásának elősegítése. Az említett internetes oldalak azonban nemcsak tájékoztatnak, hanem azon túlmenően az interaktív kommunikációt is lehetővé teszik az oldal látogatói számára. Így ezzel az oldal résztvevői közötti véleménycsere és a véleménykülönbségek megvitatásának fórumává is válnak. Az e körben megjelenő hozzászólások tehát nem szerkesztett tartalmak, hanem a kommunikáció újabb keletủ változatai.

Erre hívja fel a figyelmet párhuzamos indokolásában Paczolay Péter is. Véleménye szerint az ügyben más alapjogi megközelítést kellett volna alkalmazni, hiszen a szóban forgó honlap nem tekinthető sajtóterméknek, így azt nem a sajtószabadság körében, hanem általánosan a véleménynyilvánítás szabadságával összefüggésben kellett volna vizsgálni. A sajtószabadságnak a sajtó fogalmi körén túlra való kiterjesztése szerinte kiszámíthatatlan joggyakorlathoz vezethet.

Az Alkotmánybíróság a döntés során korábbi határozataiban tett megállapításait is figyelembe vette, mivel az Alkotmány és az Alaptörvény rendelkezései lényegét tekintve azonosak a véleménynyilvánítás szabadsága és a sajtószabadság terén. 
Így megerősítette, hogy a plurális, demokratikus társadalom alapvető értékei a vélemény- és sajtószabadság, hangsúlyozta azok kitüntetett szerepét és anyajog jellegét. Megerősítette a véleménynyilvánítás és a sajtó szabadságának kettős igazolását (az egyén szubjektív véleménynyilvánítása és a demokratikus közvélemény alakítása). Továbbra is irányadónak tekintette, hogy az alkotmány a szabad kommunikációt részesíti tartalomfüggetlen védelemben, ugyanakkor a vélemény kinyilvánítása bizonyos estekben korlátozható.

A testület az internetet a kommunikáció új színtereként jelölte meg, amely azonban nem tekinthető jogmentes területnek. Megállapította, hogy az interneten folytatott nyilvános kommunikáció során is érvényesülnie kell az Alaptörvény rendelkezéseinek. Rámutatott, hogy a blogbejegyzések, illetve a kommentek is olyan közlésnek minősülnek, amelyeket az Alaptörvény IX. cikke véd. Az alapvető jog védett tárgya ugyanis maga a vélemény, melynek egyre gyakoribb megjelenési formája az internetes kommunikáció. Ennek legföbb eszköze a sajtó, mely alatt a testület minden olyan eszközt ért, amely a közléseket a nyilvánossághoz eljuttatja, tehát az internetes portálokat is. A sajtó tehát nemcsak a véleménynyilvánítás, hanem a tájékoztatás, a vélemények formálásának is az eszköze.

Annak ellenére, hogy az $A B$ hivatkozott korábbi gyakorlatára, annak szóhasználatát nem követte teljes mértékben, így némi terminológiai változás érzékelhető a sajtószabadság felfogásában. Az eltérés elsősorban a véleményszabadság és a sajtószabadság egymáshoz való viszonyával kapcsolatban mutatható ki. Korábban a sajtó eszközjellege volt meghatározó az $A B$ gyakorlatában, most viszont a határozat a sajtószabadságot vitatható módon a véleménynyilvánítási szabadság egyik különálló tényállásaként kezeli. ${ }^{13}$

Az Alkotmánybíróság általánosságban a nyomtatott sajtóval rokonította az internetet, és a két médium között csak az előállítás és a terjesztés kapcsán látott különbséget. Ezzel azonban nagyon leegyszerüsítette a helyzetet, kiemelt ugyanis egy közös jellemzőt (az információk nyilvánossághoz való eljuttatását), és nem volt tekintettel az internet számos más, a nyomtatott sajtótól eltérő tulajdonságára.

Az Alkotmánybíróság szerint egyértelmü különbséget kell tenni a szerkesztett internetes oldalak és a közösségi oldalak, illetve a tisztán véleménynyilvánításra alkalmas oldalak (például a blogoldalak, az ún. Web 2.0) között. Az utóbbiakra nem a sajtószabadság alapjoga vonatkozik, hiszen tartalmuk nem szerkesztett, nem lépnek fel tájékoztatási igénnyel, céljuk egy internetes közösségbe tartozók közötti eszmecsere megvalósítása. Éppen ezért ezeket az oldalakat az AB jelen határozatában nem vizsgálta, azokat inkább a magánjellegű közlésekhez hasonlította, mivel a véleménynyilvánító a felhasználók meghatározott csoportjának címezi bejegyzését. Mindezek alapján nem világos, hogy a testület miért nem találta a hozzászólásokat az Ektv. hatálya alá tartozónak, és az sem, hogy ennek ellenére miért tartotta szükségesnek a törvény rendelkezéseit részletesen elemezni.

$A z A B$ megállapította, hogy az internetes oldal müködtetőjének felelőssége kétségtelenül korlátozza a sajtószabadságot. A további kérdés tehát az volt, hogy ez a korlátozás alkotmányosan igazolható-e. A testület az általános alapjog-korlátozási

13 Indokolás [44]; [55]. 
tesztet alkalmazta. Ennek lényege, hogy alapvető jog kizárólag más alapvető jog érvényesülése vagy valamely alkotmányos érték védelme érdekében, a feltétlenül szükséges mértékben, az elérni kívánt céllal arányosan, az alapvető jog lényeges tartalmának tiszteletben tartásával korlátozható. ${ }^{14} \mathrm{Ez}$ azt jelenti, hogy az állam kizárólag akkor korlátozhatja alkotmányosan az alapvető jogot, ha másik alapvető jog érvényesülése vagy egyéb alkotmányos érték védelme más módon nem érhető el. Nem elég tehát az, hogy a korlátozás legitim cél érdekében történik, és az eszköz alkalmas a cél elérésére, a korlátozásnak meg kell felelnie az arányosság követelményének is: az adott cél elérésére alkalmas legenyhébb eszközt kell alkalmazni.

A tesztet a jelen esetre alkalmazva a testület úgy találta, hogy a szabályozás alkotmányosan igazolt célja a személyiségi jogok védelme. A szabályozást a cél elérésére alkalmasnak ítélte, mivel az oldalak üzemeltetőjének felelőssége nélkül a sérelmet szenvedett fél elégtétel nélkül maradna. Az arányosság vizsgálatánál két szempontra volt figyelemmel. Egyrészt, hogy arányos-e az oldal fenntartójának felelössé tétele a jogsértő közlésért, másrészt, hogy a felelősség mértéke arányos-e.

$A z A B$ szerint az előzetes moderálás nélkül müködő oldal fenntartójával szemben a jogsértés megállapítása arányosnak tekinthető, ugyanis a moderált internetes kommentek jogsértő tartalmáért való felelősség a legenyhébb, a cél elérésre alkalmas korlátozása a sajtószabadságnak. Az $A B$ amellett érvelt, hogy a kommenteket moderáló és nem moderáló oldalak felelőssége a jogsértés bekövetkezése után azonos. A moderálás ugyanis nem mentesít a felelősség alól, az magán a jogsértés tényén alapszik. Ezt elfogadva pedig a moderált és nem moderált kommentek között az alapjog-korlátozás arányosságát tekintve sem tartotta ésszerűnek a különbségtételt. Így a testület - a vizsgálatot rövidre zárva - megállapította, hogy mivel a moderált kommentekért való felelősséget az indítványozó sem vitatta, az arányosság kérdése tulajdonképpen nem merül fel.

$A z$ arányossági vizsgálat szükségessége emellett a kártérítés összegével kapcsolatban vetődött fel. Erre vonatkozóan az $A B$ azt állapította meg, hogy a kérdésröl csak a jövőben, az ehhez kapcsolódó alkotmányjogi panaszok során tud majd dönteni. Hozzátette, hogy ennek megállapítása során is figyelemmel kell majd lenni a véleménynyilvánítás és a sajtó szabadságára. Ennek szempontjairól azonban hallgatott, bizonytalan helyzetet teremtve mind a jogot követni igyekvő állampolgárok, mind a jogalkalmazók számára.

Könnyen belátható az arányosság körében vizsgált mindkét aspektus tekintetében, hogy az Alkotmánybíróság többségének érvelése formális, nem alapjogi érvelés. Nem derül ki ugyanis, hogy a szólás- és sajtószabadság igazolásai, az alapjog célja és tartalma alapján ez a korlátozás miért minősül arányosnak. ${ }^{15}$

Különvéleményében Stumpf István is az arányossági vizsgálat „rendhagyó” voltára világít rá. Véleménye szerint a testület nem végezte el szisztematikusan a szükségességi-arányossági tesztet, és figyelmen kívül hagyta a moderált és moderálás nélküli oldalak közötti, alapjogi szempontból rendkívül fontos minőségbeli különbsé-

14 Magyarország Alaptörvénye (2011. április 25.), Szabadság és Felelősség I. cikk (3) bekezdés.

15 Hiányzik az alapjogi érvelés egy lényeges eleme, a morális értelmezés. Lásd részletesebben: TótH Gábor Attila: A szólás méltósága, Századvég, 2008/2., 129-130. 
get. Mivel a moderált oldalak esetében tudatos döntés következtében kerülnek ki a tartalmak az oldalra, a moderálás nélküli oldalaknál azonban ez hiányzik, szerinte a felelősséget érintő arányossági kérdésben az egyikről tett megállapításokat a másikra nem lehet alkalmazni. Az alkotmánybíró szerint nem körvonalazhatók a többségi indokolásban azok az ismérvek, amelyek alapján a korlátozás arányosnak minősült, és azok sem, amelyek alapján mások viszont aránytalannak minősülnének.

A fenti szempontok hiányát Paczolay Péter is problémásnak találta. Véleménye szerint arra tekintettel, hogy az Alkotmánybíróság elöször foglalkozott a moderálás nélküli hozzászólásokért való felelösséggel, több szempontot kellett volna figyelembe vennie. Olyan differenciálásra lett volna szükség, amely alkotmányos egyensúlyt teremt a szólásszabadság és a személyiségvédelem között. Így eltérően kellett volna megítélni a beazonosítható személytől származó és a névtelen kommenteket, illetve a felelősség objektív és a felróhatóságon alapuló szubjektív jogkövetkezményeit. Összességében az volt a véleménye, hogy e szempontok mérlegelésének hiánya a késöbbiekben aránytalanul korlátozó döntésekhez vezethet.

Annak ellenére tehát, hogy az $A B$ kellően részletesen idézte azokat az alkotmányos elveket és követelményeket, melyeket a szólás- és sajtószabadságról korábban maga tett, jelen határozatban a mérlegelés során azokra egyáltalán nem volt tekintettel. Jóllehet az indokolásban a testület egyértelmúen kijelentette, hogy az internetes oldal müködtetőjének felelősségét csak alkotmányjogi szempontból vizsgálja, az alapjogi vizsgálat tulajdonképpen elmaradt. Úgy tủnik, az általános alapjogkorlátozási teszt alkalmazásakor a vizsgált alapjogra egyáltalán nem volt tekintettel a testület. Ennek eredménye egy, az alapjog alanyi és intézményi oldalát teljesen figyelmen kívül hagyó, logikátlan következtetés.

\section{3. Összegzés}

Az Alkotmánybíróság felemás határozatot hozott. Egyrészt továbbra is hangsúlyozta a szólás- és sajtószabadság fontosságát a demokratikus társadalomban. Felismerte, hogy az internet is a kommunikáció színterévé vált, így az alapjogok értelmezése a kibertérre vonatkoztatva is szükségessé vált. A szólásszabadság körében általa részletesen kimunkált alkotmányos elvek felidézése után azonban következtetése nem a demokratikus vita és az egyéni önkifejezés megvalósulását segítette elő. A döntés nem volt teljes mértékben tekintettel az internet sajátosságaira, $s$ annak a vélemény- és sajtószabadságban betöltött kiemelkedő szerepére.

Összességében elmondható, hogy a határozat logikátlan következtetéssel, nem alapjogi érvelés alapján a szólást inkább korlátozó eredményt hozott. Ennek következménye az lehet, hogy egyes internetes oldalak müködtetői nem fognak lehetőséget biztosítani a hozzászólásokra, amivel az interneten való szabad kommunikáció veszélybe kerülhet. A magyar Alkotmánybíróság tehát ezzel a döntéssel a demokrácia érvényesülésében kiemelkedő szerepet játszó vélemény- és sajtószabadság érvényesítése tekintetében egy lépést nem elöre, hanem hátra tett.

A szólásszabadságot pártolók aggodalmát talán az enyhítheti, hogy a határozattal nem minden alkotmánybíró értett egyet. Ezek az eltérő vélemények azt jelzik, hogy 
a bírák között diskurzus van a kérdésröl. Ennek következtében az is elöfordulhat, hogy a következő hasonló panasz elbírálásakor egy kiforrottabb, a szólást szélesebb körben megengedő döntés születik majd.

\section{Abstract}

Restrictions on the freedom of expression have been subject to mixed and constant debates. The debates are increasing in the case of free speech on the internet. In the recent past the Hungarian Constitutional Court had to examine this problem and contribute to the discourse.This article presents Decision 19/2014 of the Hungarian Constitutional court concerning the freedom of expression on the internet. The subject-matter of the case was the liability for the comments. The study intends to show the arguable points of the Court's reasoning. 